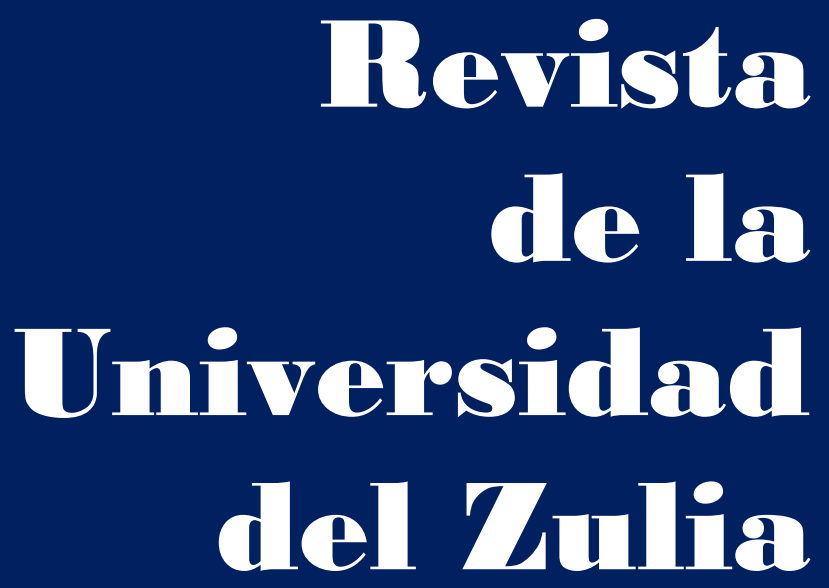

Fundada en 1947

por el Dr. Jesús Enrique Lossada

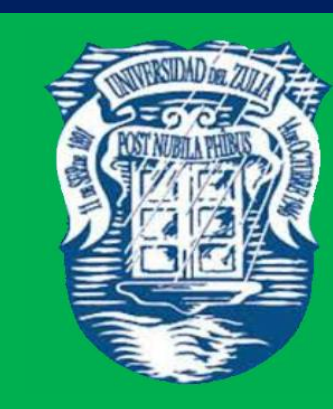

Ciencias del

Agrad,

Ingemiería

y Tecinología

\section{Aกัต 13 No $\mathbf{3 6}$} Enero - Abril 2022

Tercera Épaca

Maracailbo-Venezuela 


\title{
Strategic analysis of the demand for satellite communication services in the telecommunications market and construction of marketing strategy
}

\author{
Natalia V. Komarova* \\ Sergey I. Slav**
}

Anastasia M. Tikhomirova***

\begin{abstract}
The article focuses on the strategic analysis of the demand for satellite communications services in the telecommunications market, degree of development of the problem, object, topic, initial assumption and goal of the research. A study of the telecommunications market by its key segments was carried out. The classification of key segments was chosen based on the criterion of the list's minimalism and not allowing double accounting of revenue, which is possible with $\mathrm{B} 2 \mathrm{~B}$ and then $\mathrm{B} 2 \mathrm{C}$ chains. The most rapidly developing segment of the market, which is mobile communications, has been identified. The problems and prospects of the development of such market segments as mobile communications, fixed voice telephony, broadband Internet access and television are studied. The revenue's distribution of the global telecommunications market by regions is considered. The change in the cost of mobile Internet in the countries of the world and the correlation of mobile communication's price with the cost of signal delivery lines to base stations are determined. The introduction coefficient of broadband Internet access provided by such wired lines as an optical fiber communication line, twisted pair and power supply lines of the network is considered.
\end{abstract}

KEY WORDS: consumers; marketing; mobile communication; satellites; telecommunications networks.

*Moscow Aviation Institute (National Research University), 125993 Volokolamskoe highway 4, Moscow, Russia. ORCID: https://orcid.org/0000-0003-3717-5659. E-mail: komarova_mai@mail.ru

**Moscow Aviation Institute (National Research University), 125993 Volokolamskoe highway 4, Moscow, Russia. ORCID: https://orcid.org/0000-0002-4250-8799. E-mail: ssiradist@mail.ru

***Moscow Aviation Institute (National Research University), 125993 Volokolamskoe highway 4, Moscow, Russia. ORCID: https://orcid.org/0000-0003-0991-0505. E-mail: kmrikl@yandex.ru

Recibido: 01/09/2021

Aceptado: 29/10/2021 


\section{Análisis estratégico de la demanda de servicios de comunicaciones por satélite en el mercado de telecomunicaciones y construcción de estrategia de marketing}

RESUMEN

El artículo se enfoca en el análisis estratégico de la demanda de servicios de comunicaciones por satélite en el mercado de las telecomunicaciones, grado de desarrollo del problema, objeto, tema, supuesto inicial y meta de la investigación. Se realizó un estudio del mercado de las telecomunicaciones por sus segmentos clave. La clasificación de los segmentos clave se eligió con base en el criterio del minimalismo de la lista y no permitiendo la doble contabilización de los ingresos, lo que es posible con las cadenas B2B y luego B2C. Se ha identificado el segmento del mercado de más rápido desarrollo, que son las comunicaciones móviles. Se estudian los problemas y perspectivas de desarrollo de segmentos de mercado como las comunicaciones móviles, la telefonía vocal fija, el acceso a Internet de banda ancha y la televisión. Se considera la distribución de ingresos del mercado global de telecomunicaciones por regiones. Se determina el cambio en el costo de Internet móvil en los países del mundo y la correlación del precio de la comunicación móvil con el costo de las líneas de entrega de señal a las estaciones base. Se considera el coeficiente de introducción del acceso a Internet de banda ancha proporcionado por líneas cableadas como una línea de comunicación de fibra óptica, par trenzado y líneas de suministro de energía de la red.

PALABRAS CLAVE: consumidores; marketing; comunicaciones móviles; satélites; redes de telecomunicaciones.

\section{Introduction}

Relevance of the research topic and problem statement: the study is devoted to the selection of activities of the Russian company: Russian Satellite Communications Company, which owns an orbital group in GSO in the world satellite communications market.

Competition within the satellite communications market is very fierce. The number of satellite operators with their space fleets has recently increased, as some states have entered this market by creating their own operators in order to protect their national interests. The active implementation of projects began in other types of orbits, in particular in low-orbit (at an altitude of $160 \mathrm{~km}$ - $2000 \mathrm{~km}$ ): OneWab (Great Britain) and Starlink (USA).

The largest players in the global satellite communications market are three leaders: SES (Luxembourg, founded in 1958; 47 spacecrafts in GSO) (SES.com, 2021), Intelsat 
(Luxembourg, founded in 1964; 49 spacecrafts in GSO) (Intelsat.com, 2021) and Eutelsat (Paris, France, founded in 1977; 34 spacecrafts in GSO) (Eutelsat.com, 2021).

If we talk about Russian satellite communications market, there are two satellite communications operators with their own space fleet: Russian Satellite Communications Company (12 spacecrafts) and Gazprom Space Systems (4 spacecrafts). Thus, the issues of strategic planning and the study of the demand for satellite communications services for Russian operator are currently very relevant.

As a scientific hypothesis of the study, the authors accepted and proved that marketing planning based on identifying the demand for certain satellite communication services will allow Russian Satellite Communications Company to reduce its costs and increase work efficiency and will definitely strengthen its competitiveness in the global market.

The degree of elaboration of the problem: the main problems of development and increasing the competitiveness of satellite communications were considered by a large number of researchers and presented in the previous works of the authors.

In the article "On the prospects for the development of the satellite orbital constellation of Russian Satellite Communications Company" there are the main directions of development of satellite communications (Euroconsult-ec.com, 2019). In his opinion, these are tele- and radio broadcasting and satellite broadband access in Ka-band. He is also a supporter of a restrained company development policy and for the use of proven technologies and methods, in connection with which it is impossible to imagine the company as a pioneer in the global market.

\section{Theoretical Basis}

The research used the theory of strategic competitive analysis (Ageeva et al., 2012; Novikov, 2018). According to this theory, in order to study the demand for satellite communication services, it is necessary to identify all possible competitors, determine the key factors of the company's success, segment the market, identify links between individual market segments and assess the key values for consumers of the space segment in GSO (Novikov, 2018).

Further, the work used the classical theory of marketing and strategic marketing (Mikhailova, 2020). 


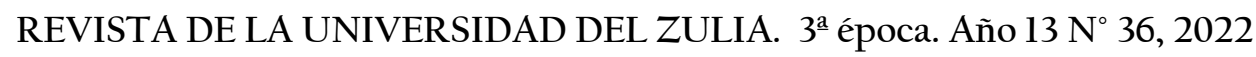
Natalia V. Komarova et al. /// Strategic analysis of the demand for satellite communication services ... 257-275 DOI: http://dx.doi.org/10.46925//rdluz.36.17

In accordance with the theory set forth in earlier works (Komarova \& Slav, 2021), a strategy for increasing the competitiveness of satellite communications in the telecommunications market was developed and in works (Komarova et al., 2019; Novikov et al., 2019a; Novikov et al., 2019b; Novikov et al., 2020) a strategy for personnel management, within which it is possible to use network working groups.

\section{Methodology of Research}

The methodological basis of the study was formed by the concepts and views of Russian and foreign experts in the field of communications and scientific workers.

Virtually all alternative types of communication are competitors of the company under consideration, therefore, we will consider all sectors of the telecommunications market. In addition, due to the high cost of equipment for organizing a satellite communication line, the main consumers of the space segment are companies operating in other sectors of the telecommunications market.

The object of the research is the competitiveness of Russian operator in the global satellite communications market. The subject of the research is the selection of directions in the company's activities and the formation of a new range of services. Purpose of the study: on the basis of theoretical studies of the telecommunications market and identified new directions in the company's activities in the field of satellite communications, to develop a new marketing strategy for its development, including product policy, pricing policy, formation of demand and stimulation of sales and distribution policy.

\section{Results and Discussion}

The telecommunications market is a huge industry with $\$ 1.633$ trillion in revenue, which is $1.2 \%$ of world GDP.

The telecommunications market is divided into several key segments:

- mobile communications (mobile) (53\%);

- fixed voice $(9.9 \%)$;

- broadband Internet access (broadband, fixed data) $(22.8 \%)$;

- television (TV) (14.3\%).

The classification was chosen based on the minimalism of the list and avoiding double counting of revenue, which is possible with B2B chain and then B2C. 
REVISTA DE LA UNIVERSIDAD DEL ZULIA. $3^{\text {a }}$ época. Año 13 N³6, 2022 Natalia V. Komarova et al. /// Strategic analysis of the demand for satellite communication services ... 257-275 DOI: http://dx.doi.org/10.46925//rdluz.36.17

Satellite communications were not included in this classification due to the fact that in most cases it is B2B and is taken into account in the given data. The volume of revenue coming from all satellite communications is no more than $1.5 \%$.

Figure 1. EMEA (Europe, the Middle East and Africa) region (Chartsbin.com, 2021)

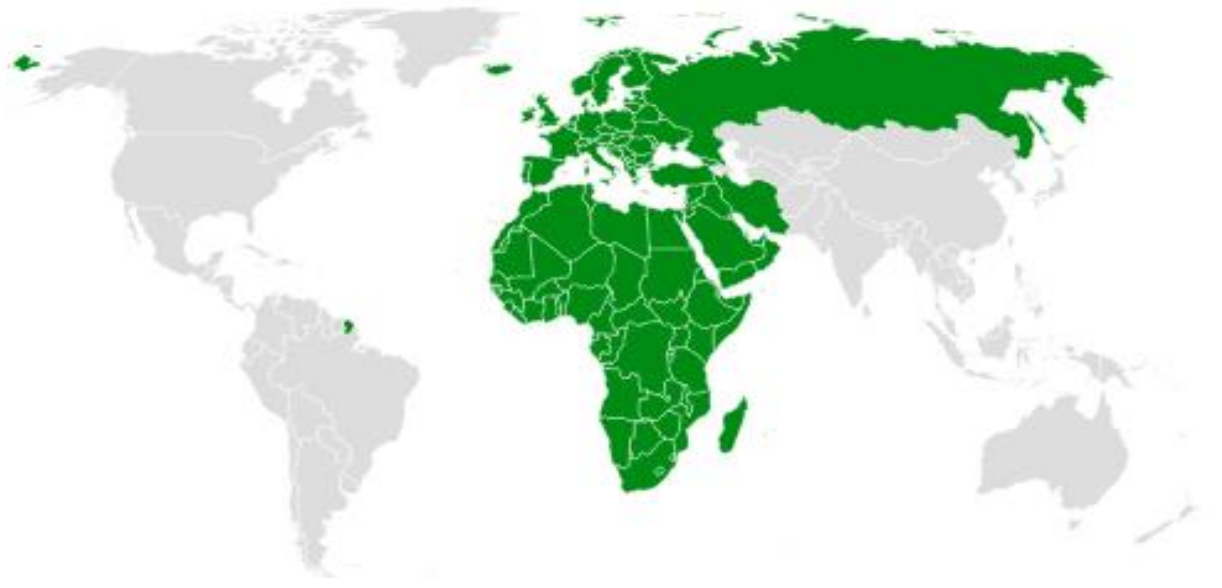

We consider the distribution across global regions. The leader in terms of absolute and specific revenue is the Americas. At the same time, growth rates in EMEA region (Figure 1) are twice as high as in other regions.

The most rapidly developing segment is mobile communications. In some countries, there are 2 or more SIM cards for each person (Figure 2), which indicates the availability of mobile communications to a wide range of the population (Chartsbin.com, 2021).

Figure 2. Mobile introduction rate in the countries of the world (coefficient of $100 \%$ or more says that some residents have 2 or more subscriptions) (Chartsbin.com, 2021)

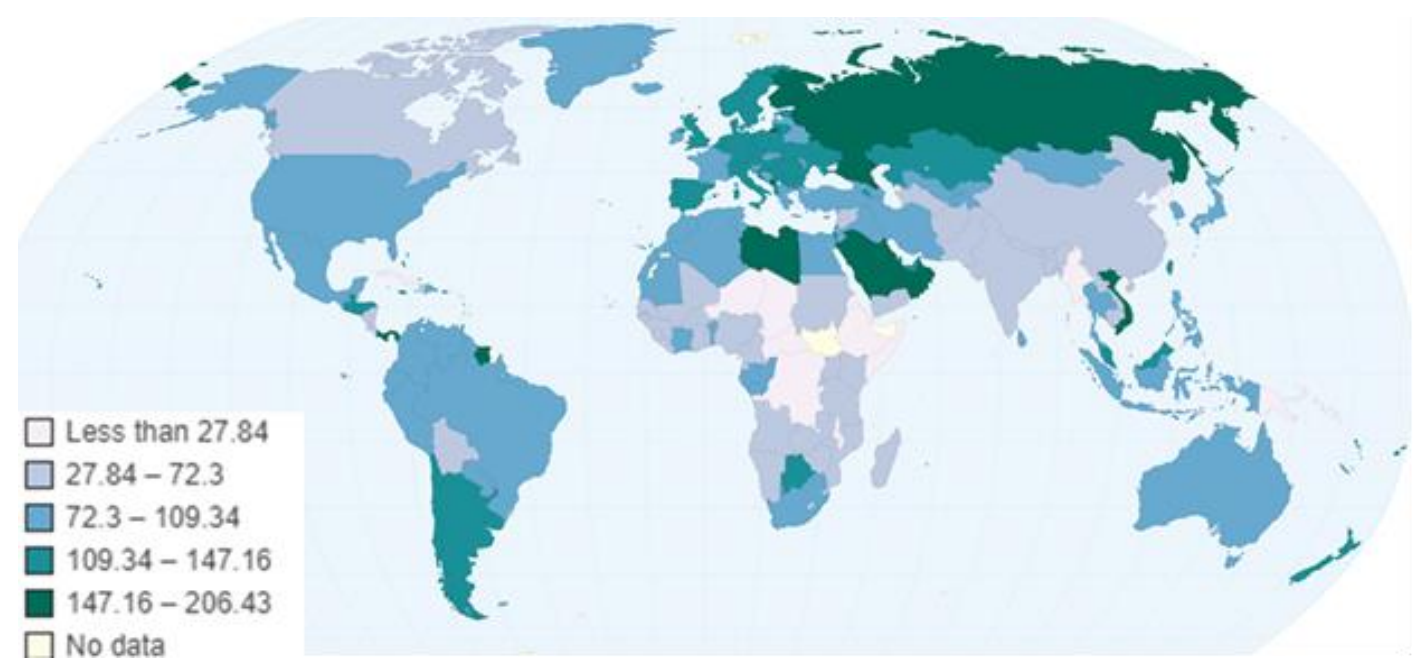


REVISTA DE LA UNIVERSIDAD DEL ZULIA. $3^{a}$ época. Año $13 \mathrm{~N}^{\circ}$ 36, 2022 Natalia V. Komarova et al. /// Strategic analysis of the demand for satellite communication services ... 257-275 DOI: http://dx.doi.org/10.46925//rdluz.36.17

The industry began a long time ago, but its explosive growth began with the advent of $2 \mathrm{G}$ technology in the 1990s, which heralded the beginning of the digital mobile era. Since 1998 to 2019 the price per minute of conversation has decreased almost hundreds of times: from 0.83 to 0.01 US dollars (taking into account inflation, this is approximately from 1.32 to 0.01 US dollars) (Vc.ru, 2021).

Today, mobile communication is not only voice messages, but also broadband Internet access. The Figure 3 shows the cost of 1 GB of Internet traffic for a mobile network (Chartsbin.com, 2021). It depends on the level of prosperity of the country's citizens and on the level of development of the mobile network. The worst of all is in African countries, where the cost of 1 GB of traffic can go up to hundreds of US dollars. In such countries, satellite communications can reduce the cost of mobile communications.

Mobile Internet access appeared in 2.5G networks. At the moment, active development of $5 G$ technologies begins, which has a number of advantages over $4 G$ networks:

- Latency has been reduced from $50 \mathrm{~ms}$ to $1 \mathrm{~ms}$ by reducing the size of the subcarrier and slots. This is the delay from the mobile station to the subscriber. In reality, the signal delay between two subscribers is greater (about $10 \mathrm{~ms}$ ). For satellite communications it is from $240 \mathrm{~ms}$ or more;

- Speed increased from 160 Mbps to 11 Gbps (in theory, in reality, the microchip of the Snapdragon X55 5G modem allows achieving 7 Gbps speed when using MIMO 4x4, due to increase in spectral efficiency by $16.7 \%$ and bandwidth for one channel.

Increased subscriber density per sq. $\mathrm{km}$. from 1 thousand to 1 million, due to the reduction of slots and cell sizes.

All this became possible thanks to a technological breakthrough in microelectronics, which allows increasing productivity with the same power consumption.

To implement 5G technologies, more frequency resource will be required, since wider carriers are needed, and at 900/1800 MHz it is impossible to work with such parameters and we need to climb "up". In this connection, $5 \mathrm{G}$ needs a frequency spectrum assigned to satellite communications: 3.4-3.8 GHz, i.e. half of C-band frequencies. The measures taken recently by Russian government (Dmitriev \& Novikov, 2019a; Dmitriev \& Novikov, 2019b; Dmitriev 
REVISTA DE LA UNIVERSIDAD DEL ZULIA. $3^{a}$ época. Año $13 \mathrm{~N}^{\circ}$ 36, 2022 Natalia V. Komarova et al. /// Strategic analysis of the demand for satellite communication services ... 257-275 DOI: http://dx.doi.org/10.46925//rdluz.36.17

\& Novikov, 2020) have helped to increase the amount of consumed frequency resource. Some operators are laying frequencies and $\mathrm{Ka}$-band (20-30 GHz).

Figure 3. Estimated average cost of subscription in different regions of the world and percentage of prepaid tariffs (Chartsbin.com, 2021)

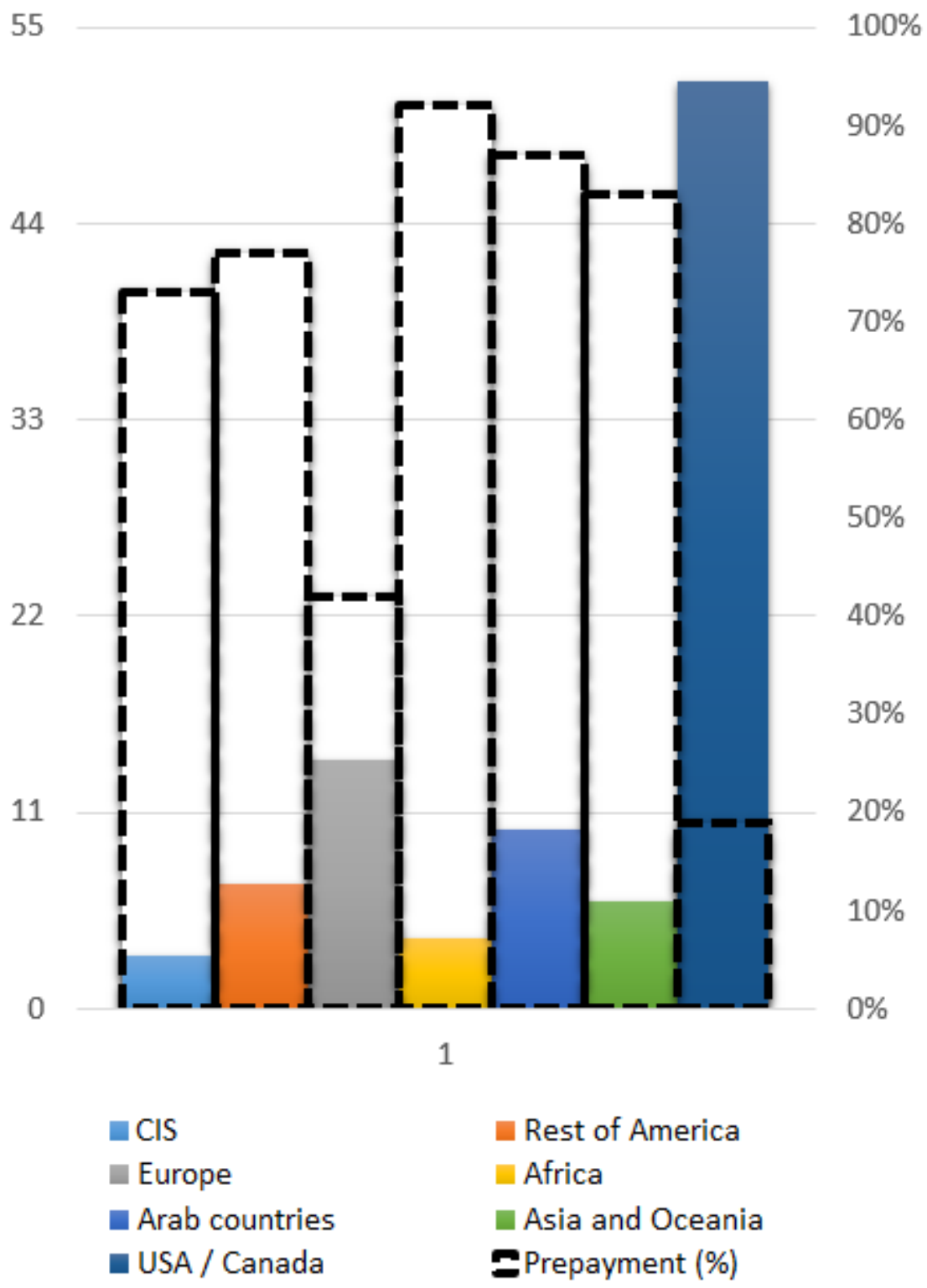

Future mobile networks may not be 5G compliant, just like current 4G networks. All technologies such as LTE and WiMAX are essentially 3.75G networks.

By its properties, mobile communication is a "last mile" technology. The range of mobile towers is usually from $0.5 \mathrm{~km}$ to $7 \mathrm{~km}$. In theory, a 100 -meter tower can "finish off" up to $37 \mathrm{~km}$, but in practice there are many restrictions, including restrictions on power and 
REVISTA DE LA UNIVERSIDAD DEL ZULIA. $3^{a}$ época. Año $13 \mathrm{~N}^{\circ}$ 36, 2022 Natalia V. Komarova et al. /// Strategic analysis of the demand for satellite communication services ... 257-275 DOI: http://dx.doi.org/10.46925//rdluz.36.17

sanitary and epidemiological standards with a minimum quality of communication. The cost of mobile communications is highly correlated with the cost of signal delivery lines to base stations.

Figure 4. Cost of 1 GB of mobile Internet in the countries of the world (Chartsbin.com, 2021)

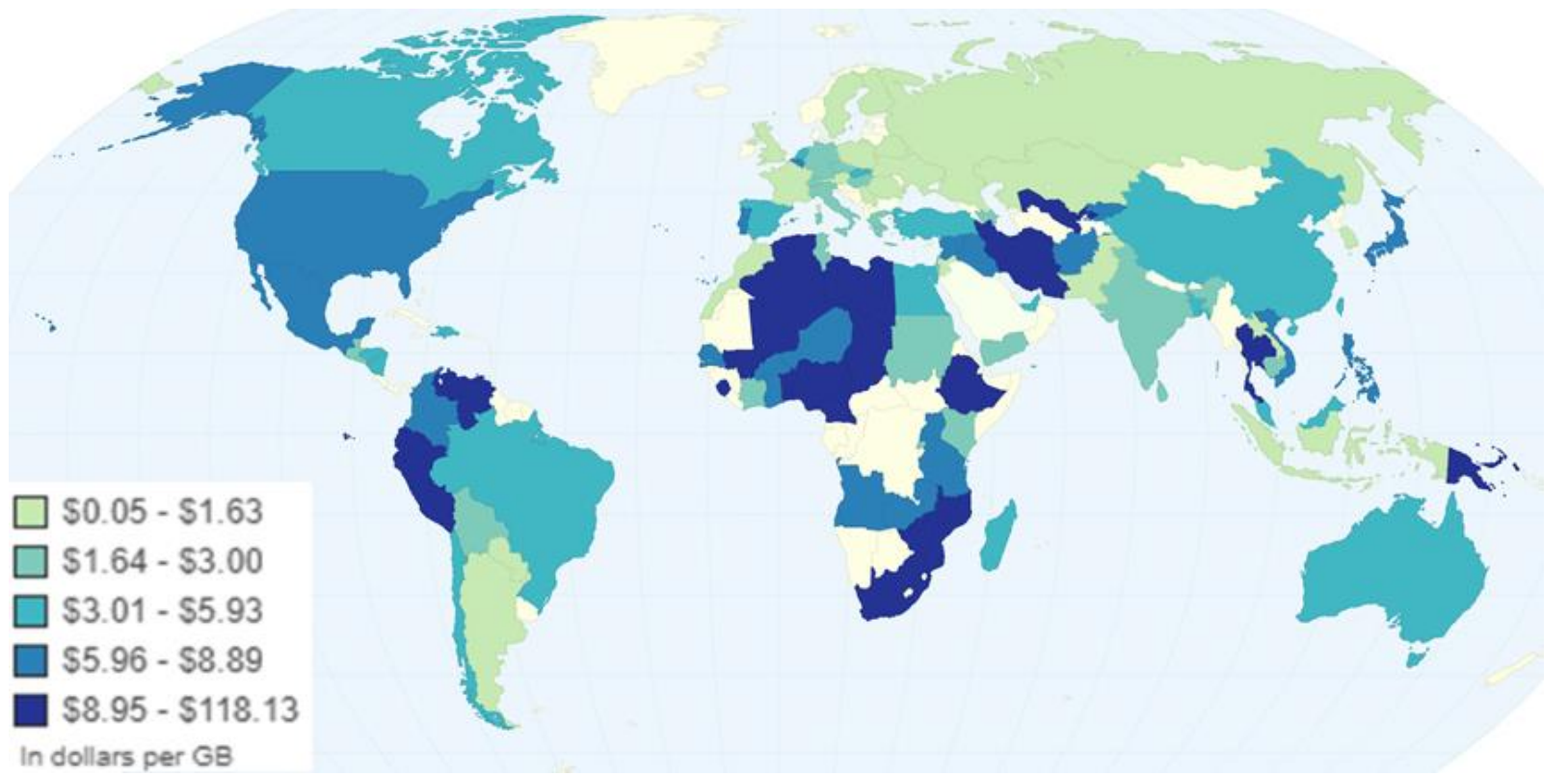

Satellite communication is used to deliver Internet traffic to base stations located in places where it is impossible to lay fiber optic communication lines or other communication lines. Also, satellite communication can serve as a backup communication line in those places where there is only one fiber optic communication line.

The Figure 4 illustrates data on ARPU (Average revenue per user) and percent of prepaid tariffs. The share of mobile Internet is growing, as voice calls using applications such as Scype, WhatsApp, Viber, etc. are cheaper.

The absolute leaders in terms of revenue from mobile communications are the United States ( $-30 \%$ of revenue worldwide). The share of Russia is just over $1 \%$ of the world, while before 2014 the share was almost $2 \%$.

Fixed voice (telephone) communication is going through hard times and is a clear outsider among all markets. The decline in the fixed-line market began in 2006. In developed countries, this process began in 2001. Here, mobile communications and broadband access (VoIP) began to oppress long ago, in connection with which it is losing the position (Figure 5) (Chartsbin.com, 2021). Due to its low cost and optimized specifically for voice traffic, it is 


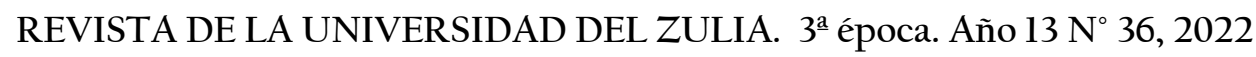
Natalia V. Komarova et al. /// Strategic analysis of the demand for satellite communication services ... 257-275 DOI: http://dx.doi.org/10.46925//rdluz.36.17

actively used in corporate networks. At the same time, they are combined with digital enhanced cordless telecommunication (DECT) radiotelephony technologies from mobile communications, using as the "last mile".

Figure 5. Fixed voice introduction rate in the countries of the world (Chartsbin.com, 2021)

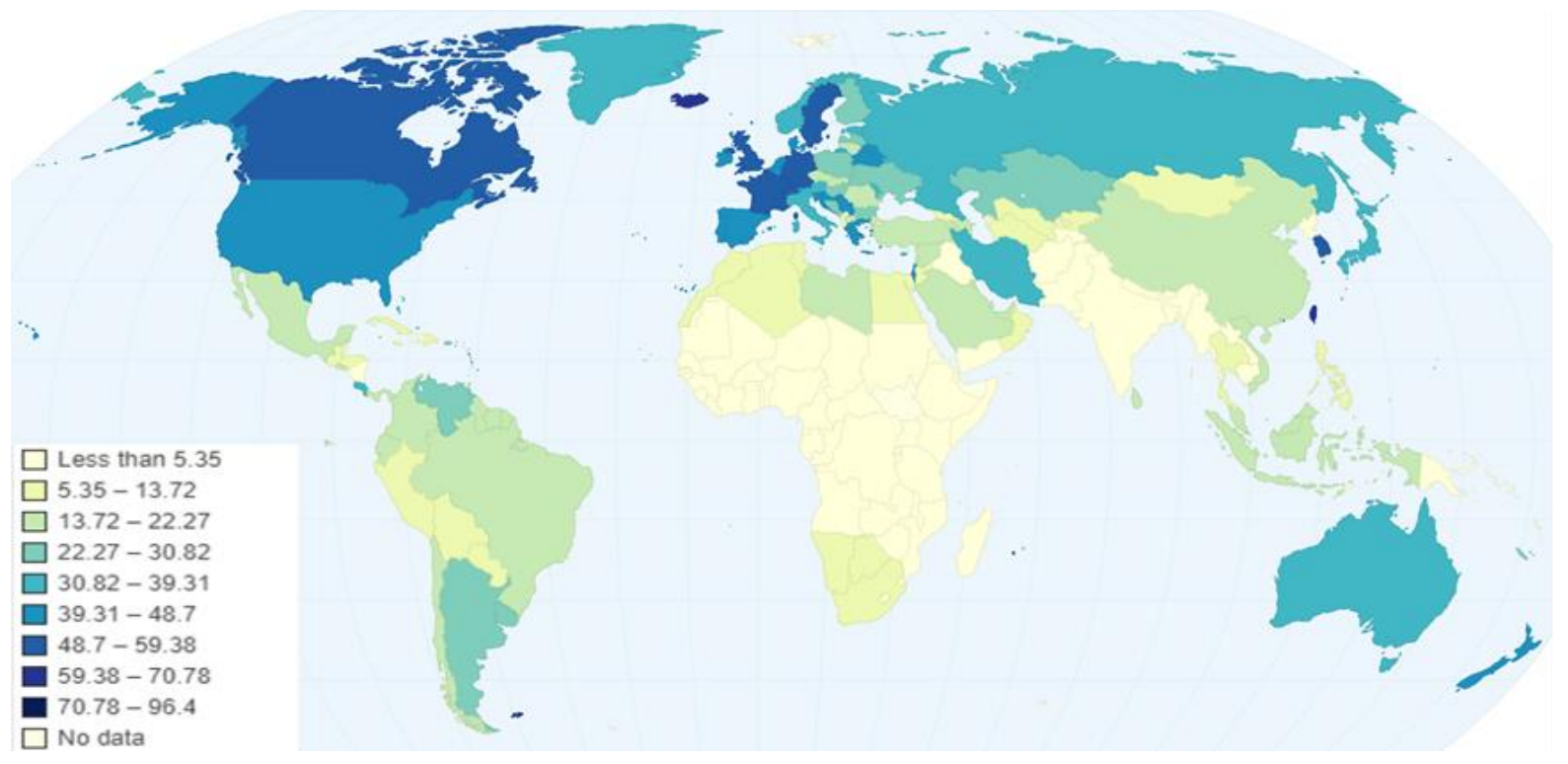

Satellite communication with its large "ping" is not very convenient for these purposes. In the world of high-speed Internet, it makes little sense to invest in voice communication as a separate area. When accessing Internet, any device such as a PC, laptop and smartphone allows organizing free voice teleconferences (Skype, Viber, WhatsApp, etc.).

Broadband Internet access is also evolving, albeit at a slower pace than mobile communications. This term denotes broadband access provided by wired lines (fiber optic communication line, twisted pair, network power lines, etc.).

Fiber optic communication lines are being actively introduced using traditional technology, i.e. to the router at the entrance and from it via twisted pair (port speed 100-1000 $\mathrm{Mbit} / \mathrm{s}$, depending on the type of port) and GPON (optics to the apartment, does not require signal recovery at a distance of $20-40 \mathrm{~km}$, i.e. it is passive), which allows one head-end station to provide Internet to 1024 subscribers (8 segments / ports for 128 subscribers) and more, at a speed of $2.4 \mathrm{Gbps}$ per port (i.e. $18.75 \mathrm{Mbps}$ per subscriber).

Broadband Internet access is well developed in America, Australia and Europe (Figure 6) (Tadviser.ru, 2020). African countries have the same problem as mobile communications. 
REVISTA DE LA UNIVERSIDAD DEL ZULIA. $3^{a}$ época. Año $13 \mathrm{~N}^{\circ}$ 36, 2022

Natalia V. Komarova et al. /// Strategic analysis of the demand for satellite communication services ... 257-275 DOI: http://dx.doi.org/10.46925//rdluz.36.17

In this connection, satellite communications have a chance to occupy their niche in this region.

Figure 6. Coefficient of introduction of broadband access in the countries of the world (Tadviser.ru, 2020)

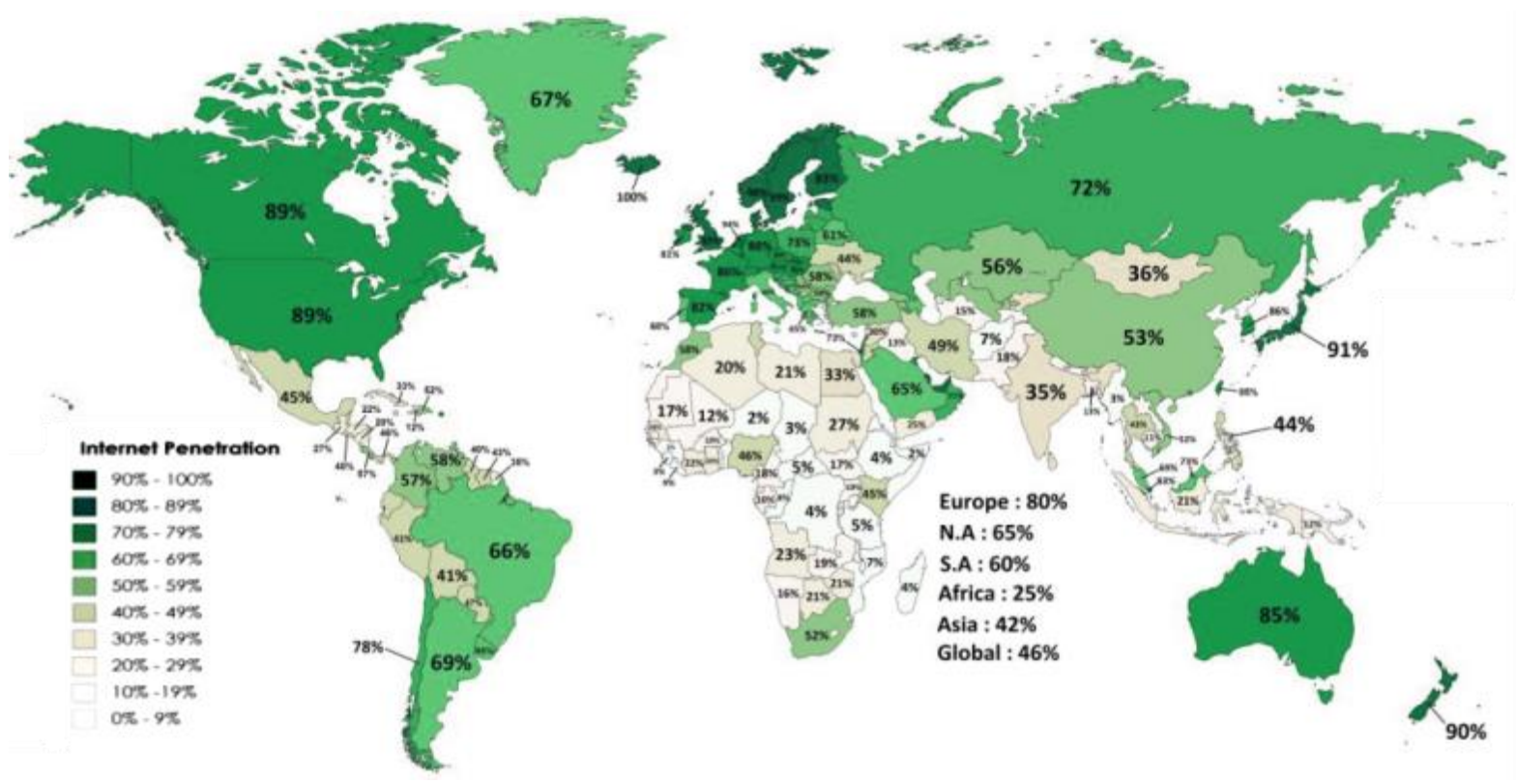

Optical communication lines drawn along the ocean floor connect only large centers (Figure 7). But it is through them that more than $97 \%$ of Internet traffic passes, since these fiber optic communication lines have a higher bandwidth than terrestrial ones and are much cheaper than land optical lines. On land, only large settlements are also connected by optical communication lines.

In Russia, a network of optical lines is developed in the European part of Russia and the border with China (Figure 8 shows the optical line of a telecommunications operator with state participation). The northern offshore line of the fiber optic communication lines, passing not far from the northern land borders of Russia, enters only at 3 points: 2 in the west and 1 in the east, that is, almost all territories of the far north of Russia are poorly developed in this regard.

Optical communication lines are actively used to deliver traffic to their head centers in mobile communications. In most cases, this is cheaper than any communication line. In this connection, the prevalence of mobile communication depends on the prevalence of fiber optic communication lines, which can be seen when comparing Figure 9 and Table 1 among themselves (Telesputnik.ru, 2019). Here satellite communication saves the situation. Many 


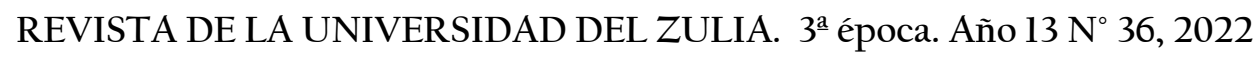
Natalia V. Komarova et al. /// Strategic analysis of the demand for satellite communication services ... 257-275 DOI: http://dx.doi.org/10.46925//rdluz.36.17 telecom operators have hubs in these territories connected through satellite communications with hubs located near the fiber optic communication line. But, since satellite communications are expensive, they are trying to lay fiber optic lines to many regions.

Figure 7. Map of fiber optic communication lines laid along the bottom of the oceans (Chartsbin.com, 2021)

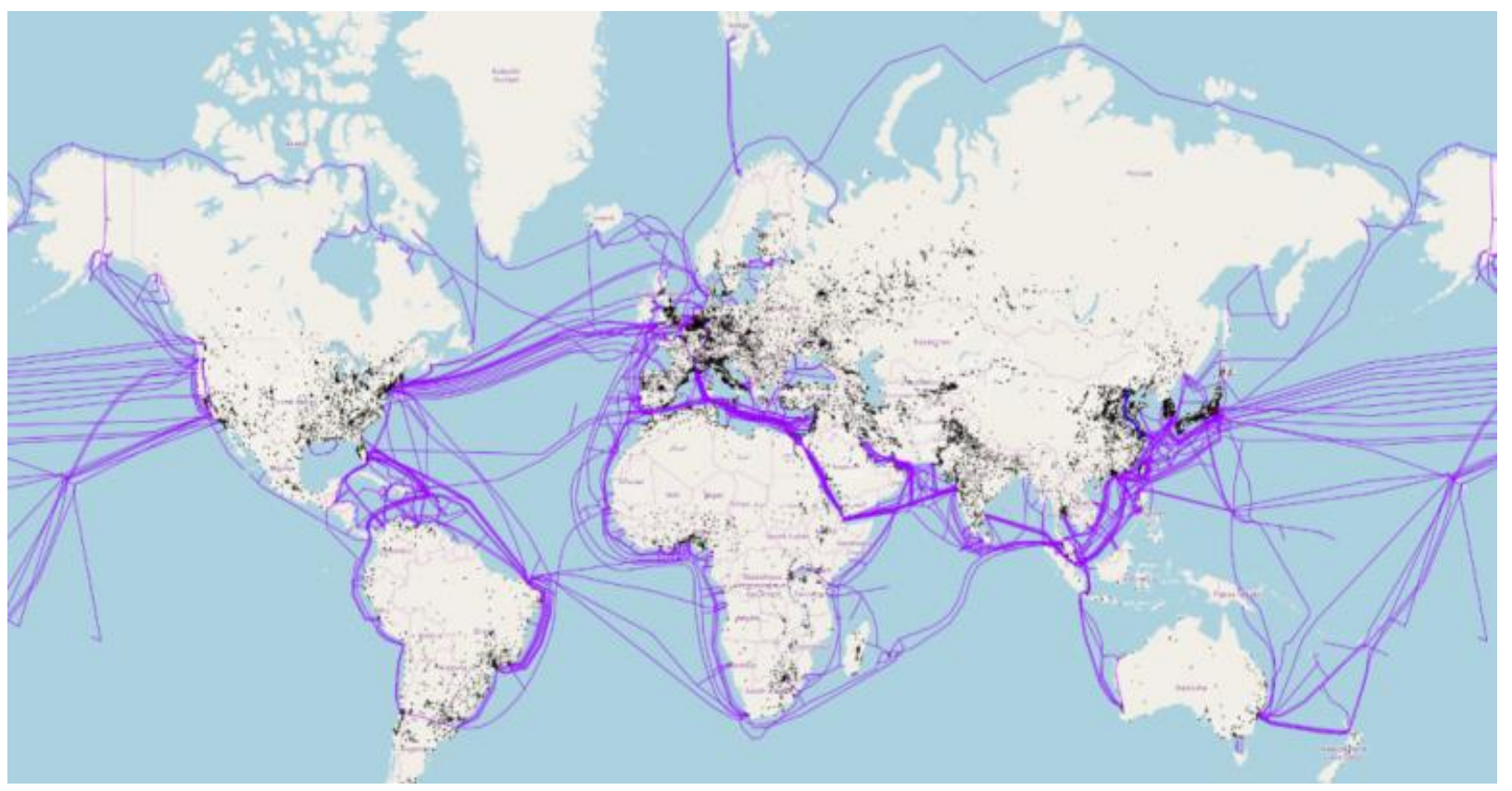

Figure 8. Backbone network Rostelecom (Chartsbin.com, 2021)

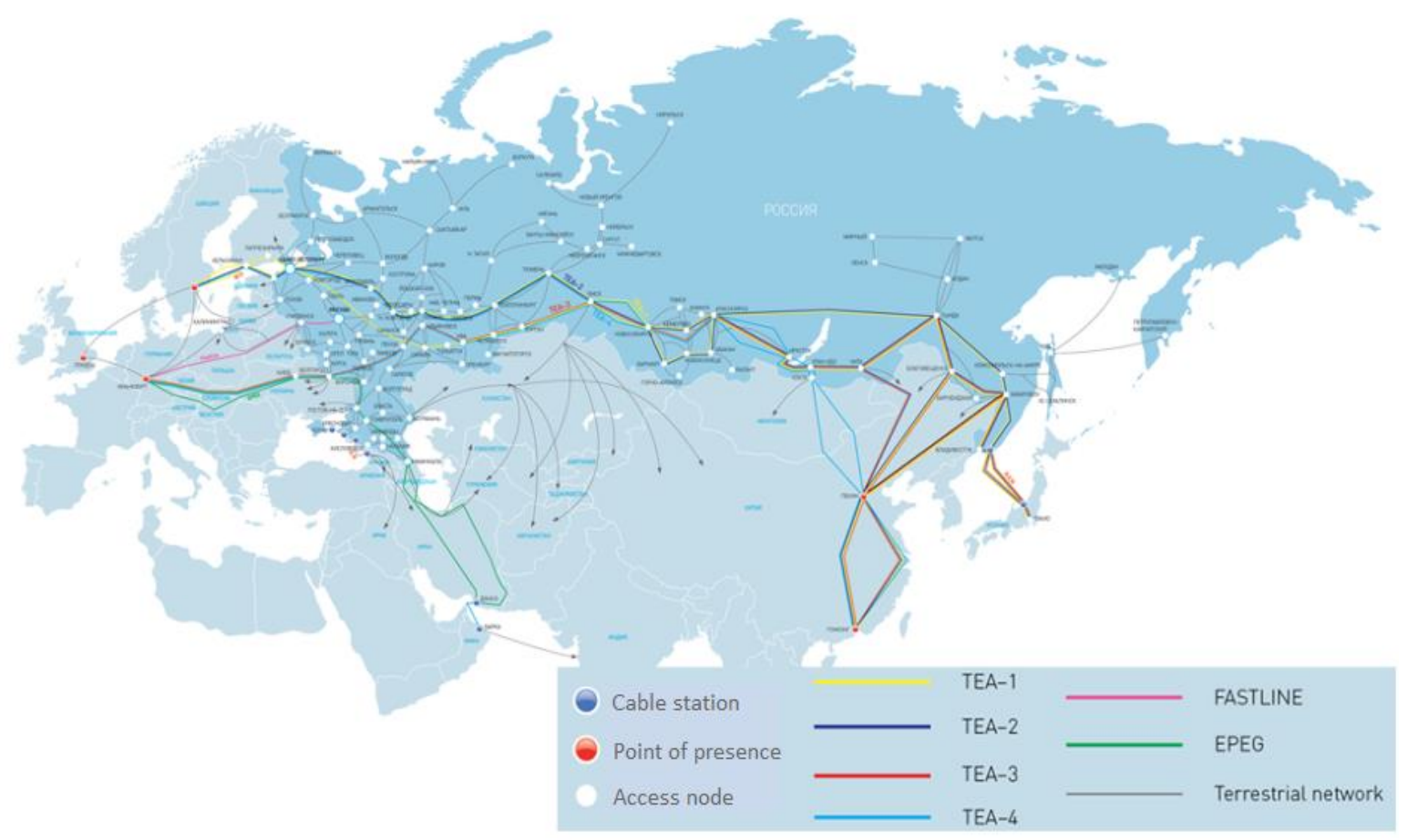


Figure 9. Mobile coverage map of the territories of Russia (Telesputnik.ru, 2019)

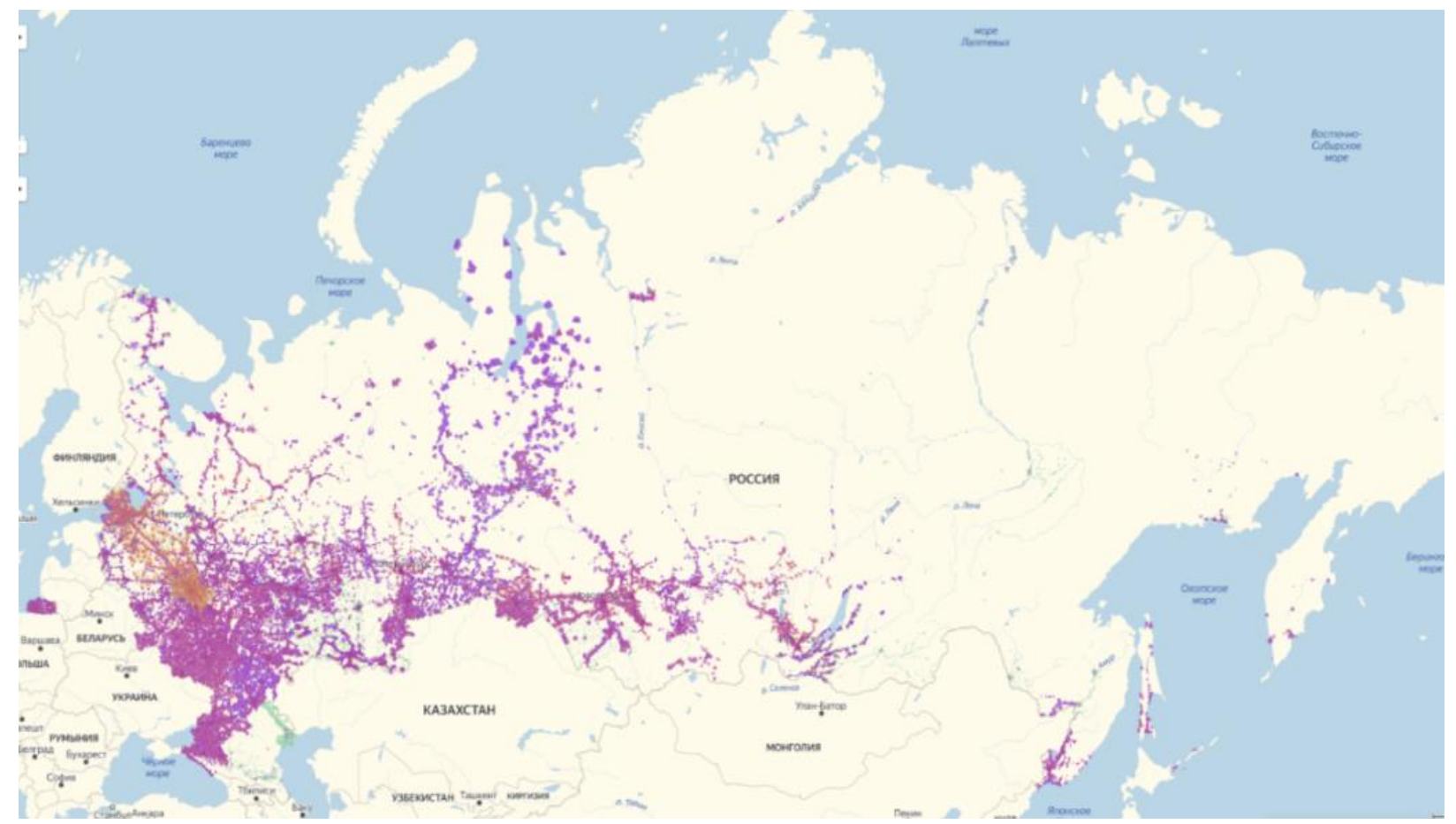

For the organization of satellite communication channels, we also have to use fiber optic communication lines. As it was mentioned earlier, all hubs of the company are connected by optical lines (2 nodes, each node has 10 GB).

Television consists of many types: terrestrial TV, IPTV, cable TV, OTT (video on Internet, for example, YouTube), SVoD (video on demand, so-called online cinemas) and satellite TV. Moreover, OTT ( $-60 \%$ of the revenue of the global TV market) and SVOD are the drivers of TV market, which in turn have a positive effect on mobile communications and broadband Internet access (Tadviser.ru, 2021).

Classic TV market is losing ground. The main problem is the lack of interactivity, which is inherent in OTT and SVoD, which works on the infrastructure of broadband and mobile communications.

Today, the standard of UHDTV $4 \mathrm{~K}$ resolution ( $3840 * 2160$ pixels) with a color depth of $3^{*} 10$ bit (HDR) is actively spreading. When used for broadcasting MPEG4 (H.265 encoder), the stream rate is from $15 \mathrm{Mbps}$ to $130 \mathrm{Mbps}$. The speed depends on the quality of the picture: from the required to Blu-Ray quality. Video bitrate on Internet can be from 11 Gbps. Video content is the main eater of Internet traffic. In this connection, the increase in the resolution and quality of the video sequence creates a demand for additional bandwidth of communication lines. 
REVISTA DE LA UNIVERSIDAD DEL ZULIA. $3^{a}$ época. Año $13 \mathrm{~N}^{\circ}$ 36, 2022 Natalia V. Komarova et al. /// Strategic analysis of the demand for satellite communication services ... 257-275 DOI: http://dx.doi.org/10.46925//rdluz.36.17

In Russia, due to a national digital TV project offering free 20-30 channels (depending on the region), Pay TV market may be severely affected. Broadcasting of 20-30 federal channels is compulsory for all Pay TV operators, which creates an additional financial burden for them. And the problem is deeper than it seems. After all, the needs of many subscribers in television are fully satisfied by free TV channels.

Satellite communication through GSO is actively used for direct television broadcasting and for moving the video stream to central television stations (in most cases, these are backup lines).

The main segments were considered by the share of proceeds. Obviously, these data are not enough to understand the vector of development of the telecommunications market. It is necessary to consider the classification by the type of traffic. The simplest of them may be this: audio-video traffic and Internet requests (requests to websites, databases, etc., including IoT).

The share of video streams in Internet traffic is very large and amounts to around 60\%. The share of video content will only grow. It is the video stream that will become the driver of the development of high-speed communication lines. For example, for video in SD (360p) resolution, the minimum required bit rate is $0.5 \mathrm{Mbps}$. For Full HD $2.5 \mathrm{Mbps}$ and for $4 \mathrm{~K}$ it is already 10 Mbps.

The share of the rest of the traffic, although it will fall, will only grow in absolute terms and at a very high rate (for example, from 2016 to 2018 the number of sites has doubled). The amount of data in IoT systems is also growing, which is used in smart homes and in industrial automation.

Today, the total average speed of all data in all types of communication is approximately 60 million Gbps. The need for the amount of information will only grow. Satellite communications can be one of the tools to reduce the digital divide around the world. For example, because of the relief or climate, it is not always possible to carry out fiber optic communication lines. In some cases, this is simply not possible, for example, for ships and aircraft.

After all that has been said, we can make a small analysis of the need for the company's services in the telecommunications market. 
REVISTA DE LA UNIVERSIDAD DEL ZULIA. $3^{a}$ época. Año $13 \mathrm{~N}^{\circ}$ 36, 2022

Natalia V. Komarova et al. /// Strategic analysis of the demand for satellite communication services ... 257-275 DOI: http://dx.doi.org/10.46925//rdluz.36.17

The most appropriate is Key Values Assessment (MPV). We divide clients by sectors: B2B, B2C, B2G (Table 1). Each of them has their own preferences.

Table l. Assessment of key values (MPV) for the consumer of the space segment in GSO
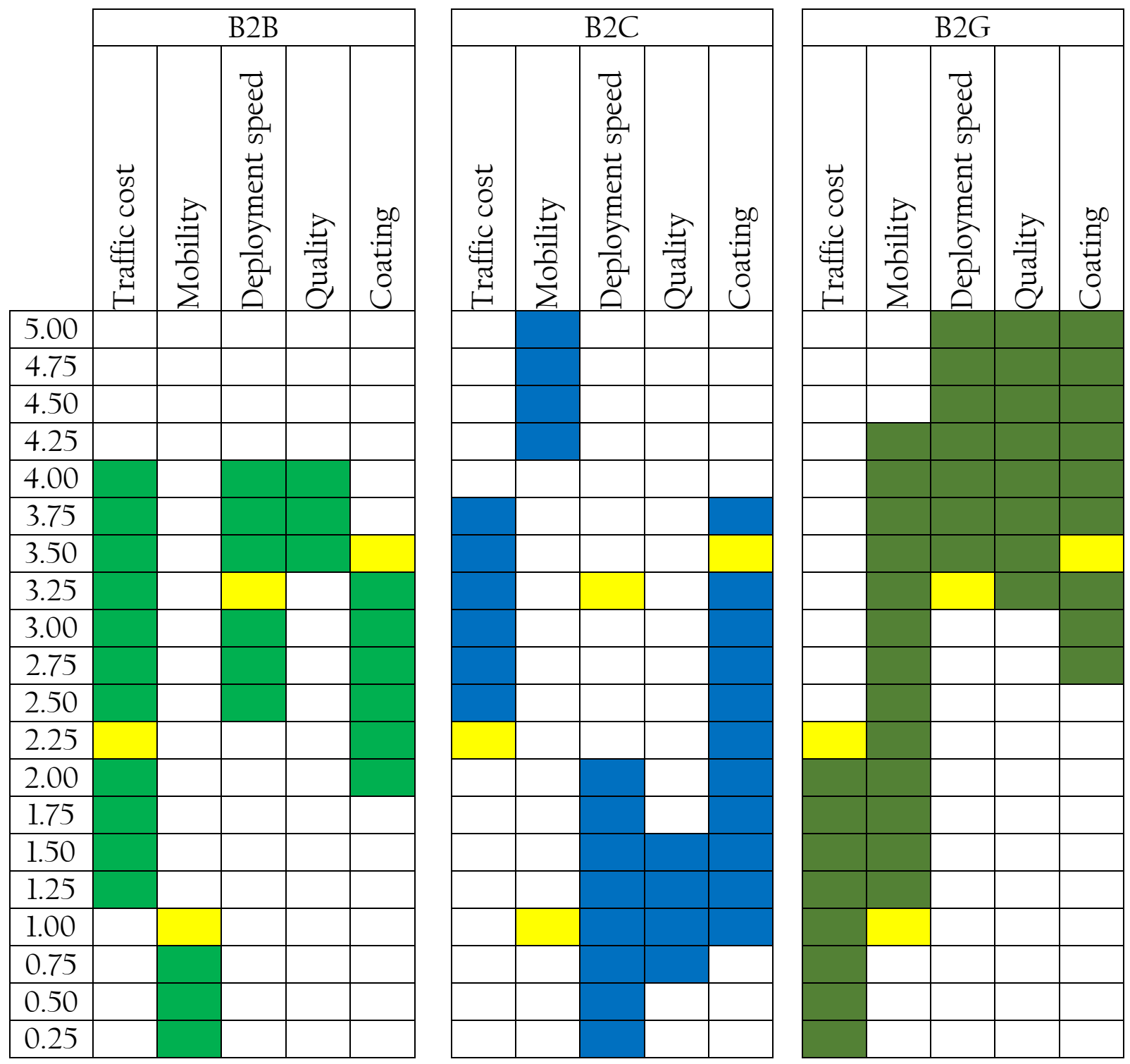

We highlight the main consumer properties of satellite communications via GSO: traffic cost, mobility, network deployment speed, communication quality and coverage area.

This assessment clearly shows that satellite communication lacks mobility, therefore it is necessary to cooperate with companies of "last mile", for example, with mobile providers, whose market share is growing.

When developing a strategy for increasing the company's competitiveness, great importance is attached to the development of a functional marketing strategy for the purpose of implementing a business positioning strategy. 
REVISTA DE LA UNIVERSIDAD DEL ZULIA. $3^{\text {a }}$ época. Año 13 N³6, 2022 Natalia V. Komarova et al. /// Strategic analysis of the demand for satellite communication services ... 257-275 DOI: http://dx.doi.org/10.46925//rdluz.36.17

We start by developing marketing goals and strategies for complex areas using 4P (product, price, place and promotion).

Products. It is important to correctly balance the product range, its characteristics and possibility of modification. It is necessary to change the product policy depending on the state of demand for products and services.

Price. It all depends on the demand for the product. Company's pricing policy changes depending on the product life cycle (Dmitriev \& Novikov, 2020).

Place. Product marketing policy must be carefully considered. Service (after-sales) in cases of exchange, stimulating repeat transactions. Additional information on other products. It is not unimportant to organize the sale of goods through other channels, for example, through intermediaries.

Promotion. Promotion of products must be constantly dealt with. The buyer must know about the product, distinguish it from the rest, in accordance with his needs and beliefs.

It is required to convey full information to the consumer (Tikhonov et al., 2020) so that he makes a decision to make a purchase of the company's services. It is necessary to maintain contact directly with the consumer. If necessary, it is necessary provide background information about the product.

Contact with customers increases company awareness, strengthens consumer confidence in the brand. The content of the presentation message is very important.

Successful trading, increasing profits still depends on the correct unique selling proposition, which will reflect the distinctive features of the product from other offers on the market today.

\section{Conclusion}

The studies have shown the need for a Russian satellite communications company to conduct a strategic analysis of the demand for services in the telecommunications market and develop a marketing strategy to increase competitiveness in the global market.

The paper presents the stages of research of the telecommunications market in such key segments as mobile communications, fixed voice communications, broadband access and television. For each of the above mentioned segments, the coefficients of introduction into 
REVISTA DE LA UNIVERSIDAD DEL ZULIA. 3a época. Año 13 N³6, 2022

Natalia V. Komarova et al. /// Strategic analysis of the demand for satellite communication services ... 257-275 DOI: http://dx.doi.org/10.46925//rdluz.36.17

the countries of the world and modern technologies of the organization were analyzed. It was revealed that the most rapidly developing segment is mobile communications. The close dependence of the development of other segments with the development of mobile communications was also determined.

Table 2. Marketing goals and strategies for complex areas

\begin{tabular}{|c|c|c|}
\hline $\begin{array}{c}\text { Complex } \\
\text { directions }\end{array}$ & Marketing objectives & Marketing strategies \\
\hline $\begin{array}{l}\text { Product-commodity } \\
\text { policy }\end{array}$ & $\begin{array}{l}\text { Create an image of a high- } \\
\text { quality product in the } \\
\text { eyes of consumers }\end{array}$ & $\begin{array}{l}\text { Design according to the requirements of the most } \\
\text { sensitive segment: high attention to quality } \\
\text { control; quick troubleshooting. Additional } \\
\text { product strategies and conditions for their } \\
\text { implementation. Focus on product quality, } \\
\text { advanced engineering and customer service }\end{array}$ \\
\hline Price policy & $\begin{array}{l}\text { Product positioning by } \\
\text { quality. Offer discounts } \\
\text { for large distributors } \\
\text { based on volume }\end{array}$ & $\begin{array}{l}\text { Offering higher dealer discounts to maintain } \\
\text { distribution channels. Using a pricing strategy to } \\
\text { move price-sensitive buyers to the next level as } \\
\text { the market segment becomes saturated. } \\
\text { Additional pricing strategies and conditions for } \\
\text { their implementation, if a large number of } \\
\text { competitors appear on the market, change the } \\
\text { pricing policy to match the prices of competitors }\end{array}$ \\
\hline Distribution & $\begin{array}{l}\text { Organize a large } \\
\text { distribution system }\end{array}$ & $\begin{array}{l}\text { Demonstration plan for dealers. Additional } \\
\text { strategies and conditions for their } \\
\text { implementation: providing dealers with large } \\
\text { discounts }\end{array}$ \\
\hline $\begin{array}{l}\text { Product policy, } \\
\text { pricing policy, } \\
\text { formation of } \\
\text { demand and } \\
\text { stimulation of sales } \\
\text { and distribution } \\
\text { policy }\end{array}$ & $\begin{array}{l}\text { Positioning a product as } \\
\text { very reliable to convince } \\
\text { the market to pay a high } \\
\text { price. } \\
\text { Maximizing market } \\
\text { coverage }\end{array}$ & $\begin{array}{l}\text { Selective use of media, personal sales, etc. Mass } \\
\text { market notification of products and services. } \\
\text { Using special promotion to increase the number } \\
\text { of consumers. Additional promotion / advertising } \\
\text { strategies and conditions for their } \\
\text { implementation: as competition intensifies, focus } \\
\text { on product differentiation strategies, focusing on } \\
\text { product differentiation, company reputation and } \\
\text { services and defensive advertising }\end{array}$ \\
\hline Profitability & $\begin{array}{l}\text { Minimum } 30 \text { percent } \\
\text { return on investment over } \\
\text { the life of the product }\end{array}$ & \\
\hline Market share & $\begin{array}{l}\text { Increase market share by } \\
20 \% \text { until } 2034\end{array}$ & Launch of new spacecraft \\
\hline Volume of sales & $\begin{array}{l}\text { Increase sales by an } \\
\text { average of } 20 \text { percent by } \\
2034\end{array}$ & Due to the new product range of the company \\
\hline $\begin{array}{l}\text { After-sales service } \\
\text { (preparation, } \\
\text { services, customer } \\
\text { relations) }\end{array}$ & $\begin{array}{l}\text { Reduce the time to } \\
\text { replace the unusable } \\
\text { resource with a new one }\end{array}$ & $\begin{array}{l}\text { Better monitoring of the resource, thus predicting } \\
\text { the problem before it appears }\end{array}$ \\
\hline
\end{tabular}


REVISTA DE LA UNIVERSIDAD DEL ZULIA. $3^{a}$ época. Año $13 \mathrm{~N}^{\circ}$ 36, 2022 Natalia V. Komarova et al. /// Strategic analysis of the demand for satellite communication services ... 257-275 DOI: http://dx.doi.org/10.46925//rdluz.36.17

It was revealed that Internet access in mobile communication appeared in $2.5 \mathrm{G}$ networks, but at present, active development of $5 \mathrm{G}$ networks is starting, which have a number of advantages presented in the work.

The frequency resource required for the implementation of the "last mile" technology in $5 G$ networks has been determined.

It was revealed that the main consumer properties of satellite communications through GSO are: traffic cost, mobility, network deployment speed, communication quality and coverage area.

During the assessment of key values for the consumer of the space segment on GSO, it was revealed that satellite communications lack mobility, in this regard, it is necessary to cooperate with companies of the "last mile", for example, with mobile providers, whose market share is growing.

The paper proposes a marketing strategy for the development of the research object, the implementation efficiency of which is increased through the use of Industry 4.0 tools, network modeling, and the use of the motivational mechanism of network project groups.

The practical significance of the study is determined and confirmed by the fact that the conclusions of this study can serve as a guide for all enterprises in the satellite communications market, both defense and civil one, faced with the problem of competitiveness in the telecommunications market.

Economic calculations have shown that for growth while keeping prices for services down, it is necessary to increase the volume of the surrendered resource over 15 years at least 2 times. At the same time, the share of additional services should be increased to 85-90\%. The average annual increase in profit from sales, while it is expected at the level of $4.5 \%$ and an average profitability in the region of $33.6 \%$.

For a more significant increase in profit, it is necessary to increase the volume of the sold frequency resource more than 2 times in 15 years.

\section{References}

Ageeva, N. G., Kanaschenkov, A. I., \& Minaev, E. S. (2012). Methods and models of strategic management. 2nded. Moscow: Publishing house "Dobroe slovo".

Chartsbin.com (2021). Retrieved at: http://chartsbin.com/ 
REVISTA DE LA UNIVERSIDAD DEL ZULIA. $3^{a}$ época. Año $13 \mathrm{~N}^{\circ}$ 36, 2022

Natalia V. Komarova et al. /// Strategic analysis of the demand for satellite communication services ... 257-275 DOI: http://dx.doi.org/10.46925//rdluz.36.17

Dmitriev, O. N., \& Novikov, S. V. (2019a). Optimizing the economic information transparency level of high-tech enterprises in the post-industrial globalized economy. International Journal of Economics and Business Administration, 7(3), 25-56.

Dmitriev, O. N., \& Novikov, S. V. (2019b). Unification and convergence of hierarchic structures such as organizational separations and product projects at creation of recommending decision support systems. International Journal of Economics and Business Administration, 7(1), 240-268.

Dmitriev, O. N., \& Novikov, S. V. (2020). A Priori Assessment of Customer Costs in Designing the Life Cycle of Complex Products. Russian Engineering Research, 40(2), 143-145.

Euroconsult-ec.com (2019). Satellite communications market to reach $\$ 19.4$ billion by 2028. Retrieved at: http://www.euroconsult-ec.com

Eutelsat.com

(2021).

Retrieved

at:

https:/www.eutelsat.com/en/satellites.html?region=+\&sservice

Intelsat.com (2021). Retrieved at: http://www.intelsat.com/globalnetwork/satellites/overview/

Komarova, N. V., \& Slav, S. I. (2021). Development of comprehensive program for the implementation of strategy to increase competitiveness in the global satellite communications market for Russian company. Journal of Physics: Conference Series, 1889(3), 032001.

Komarova, N. V., Zamkovoi, A. A., \& Novikov, S. V. (2019). The Fourth Industrial Revolution and Staff Development Strategy in Manufacturing. Russian Engineering Research, 39(4), 330-333.

Mikhailova, L. (2020). Operational Management of Flexible Production of Machine-Building Enterprises Using the Analytical Method for Optimizing Work Order Planning Services. Research in World Economy, 11, 311-319.

Novikov, S. V. (2018). Strategic Analysis of the Development of High-Technology Manufacturing Facilities. Russian Engineering Research, 38(3), 198-200.

Novikov, S., Komarova, N., \& Dadyan K. (2019a). Development of the mechanism of formation of additional capabilities of the network design team as the basis of competitive advantages of IT companies. Amazonia Investiga, 8(20), 188-199.

Novikov, S., Komarova, N., \& Dadyan, K. (2019b). Develop a system to motivate and maintain the success of internal and external interactions of the network project team. Amazonia Investiga, 8(20), 200-209.

Novikov, S., Komarova, N., \& Dadyan, K. (2020). Research opportunities to improve the competitiveness by using network project teams. Research in World Economy, 11(1), 212-219.

SES.com (202l). Retrieved at: https:/www.ses.com/ru/evropa/dobro-pozalovat-v-ses 
REVISTA DE LA UNIVERSIDAD DEL ZULIA. $3^{a}$ época. Año $13 \mathrm{~N}^{\circ}$ 36, 2022

Natalia V. Komarova et al. /// Strategic analysis of the demand for satellite communication services ... 257-275 DOI: http://dx.doi.org/10.46925//rdluz.36.17

Tadviser.ru (2020). World map by the level of Internet penetration. Retrieved at: (http://www.tadviser.ru/index.php/Статья:Интернет-доступ_(мировой_рынок)

Tadviser.ru (2021). Forecast of Allied Market Research. Retrieved at: http://www.tadviser.ru/index.php/Статья:Онлайн-видео_(мировой_рынок) .

Telesputnik.ru (2019). Research: video accounts for over 60\% of total internet traffic. Retrieved at: https:/telesputnik.ru/materials/video-v-internete/news/issledovanie-video-zanimaet-bolee60-ot-obshchego-obema-internet-trafika/

Tikhonov, G. V., Lavrova, L. A., Kolosova, V. V., Zemlyanskaya, N. B., \& Kazakova, N. V. (2020). Marketing as an Effective Control of Progressive Innovation. TEM Journal, 9(3), 10941099.

Vc.ru (2021). Prices for mobile communications: from the 90s to the present day. Retrieved at: https://vc.ru/yota/41616-mobile. 